\title{
Pengolahan Limbah Medis COVID-19 Pada Rumah Sakit
}

\section{COVID-19 Medical Waste Treatment at Hospitals}

\author{
Niki Tri Nurwahyuni ${ }^{\text {a) }}$, Laila Fitria ${ }^{\text {a) }}$, Olce Umboh ${ }^{\text {b) }}$, Dismo Katiandagho ${ }^{\text {c) }}$ \\ ${ }^{a)}$ Fakultas Kesehatan Masyarakat Universitas Indonesia, Indonesia \\ b) Dinas Kesehatan Daerah Provinsi Sulawesi Utara, Indonesia \\ c) Jurusan Kesehatan Likungan Poltekkes Kemenkes Manado, Indonesia
}

\section{A B S T R A C T / A B S T R A K}

\begin{abstract}
COVID-19 medical waste is residual material from unused reuse which is contaminated by substances that protect infectious or in contact with patients and / or hospital staff who need COVID-19 patients from service activities in the emergency room, isolation room, ICU room, treatment rooms, and other service rooms. The purpose of this study was to discover waste treatment in referral hospitals in North Sulawesi Province arising from the implementation of COVID-19 in 2020. The research was conducted on 18 of COVID-19 Referral Hospitals in North Sulawesi Province in period May - June 2020, by using cross-sectional as a research design. The results showed that 11 hospitals (61.1\%) treated COVID-19 medical waste using their own incinerator, while 7 other hospitals (38.9\%) treated COVID-19 medical waste using third-party services. All of hospitals that treat medical waste using an incinerator do not fully have an operational permit from the Ministry of Environment and Forestry. The results obtained, in an emergency (COVID-19 pandemic), are excluded from having permission to use incinerators. All health facilities are expected to carry out the process of arranging incinerator operational permit documents coordinating with the Provincial / Regency / City Health Office and Provincial / Regency / City Environment Offices, even in the COVID-19 pandemic.
\end{abstract}

Keywords:Medical waste, COVID-19, hospital, North Sulawesi

\begin{abstract}
Abstrak. Limbah medis COVID-19 adalah bahan sisa hasil kegiatan yang tidak digunakan kembali yang berpotensi terkontaminasi oleh zat yang bersifat infeksius atau kontak dengan pasien dan/atau petugas di fasyankes yang menangani pasien COVID-19 dari kegiatan pelayanan di UGD, ruang isolasi, ruang ICU, ruang perawatan, dan ruang pelayanan lainnya. Tujuan penelitian ini untuk mengetahui pengolahan limbah medis pada rumah sakit rujukan yang ada di Provinsi Sulawesi Utara yang ditimbulkan dari penanganan COVID-19 Tahun 2020. Desain penelitian adalah cross-sectional. Penelitian dilakukan terhadap 18 Rumah Sakit Rujukan COVID19 yang berada di Provinsi Sulawesi Utara pada bulan Mei - Juni 2020. Hasil penelitian menunjukkan sebanyak 11 rumah sakit $(61,1 \%)$ mengolah limbah medis COVID-19 menggunakan insinerator yang dimiliki sendiri, sedangkan 7 rumah sakit lainnya (38,9\%) mengolah limbah medis COVID-19 menggunakan jasa pihak ketiga. Dari 11 rumah sakit yang mengolah limbah medis COVID-19 menggunakan insinerator, seluruhnya tidak memiliki izin operasional dari Kementerian Lingkungan Hidup dan Kehutanan. Hasil yang didapat tersebut, dalam kondisi darurat (pandemi COVID-19), dikecualikan untuk memiliki izin penggunaan insinerator. Seluruh fasyankes diharapkan untuk melakukan proses pengurusan dokumen izin operasional insinerator walau dalam masa pandemi COVID-19 berkoordinasi dengan Dinas Kesehatan Provinsi/Kabupaten/Kota dan Dinas Lingkungan Hidup Provinsi/Kabupaten/Kota.
\end{abstract}

Kata Kunci : Limbah medis, COVID-19, rumah sakit, Sulawesi Utara

Copyright ( 2020 Jurnal Kesehatan Lingkungan All right reserved

*Alamat korespondensi : email : $\underline{\text { niki.tri@ui.ac.id }}$

\section{PENDAHULUAN}

Rumah Sakit adalah institusi pelayanan kesehatan yang menyelenggarakan pelayanan kesehatan perorangan secara paripurna yang menyediakan pelayanan rawat inap, rawat jalan dan gawat darurat. Pelayanan kesehatan paripurna dalam hal ini meliputi promotif, preventif, kuratif dan rehabilitatif ${ }^{1}$.
Dalam menjalankan fungsinya, rumah sakit menggunakan berbagai bahan dan fasilitas atau peralatan yang dapat mengandung bahan berbahaya dan beracun (B3). Interaksi rumah sakit dengan manusia dan lingkungan hidup di rumah sakit dapat menyebabkan masalah kesehatan lingkungan yang ditandai dengan indikator menurunnya kualitas media kesehatan lingkungan di rumah sakit, seperti media air, udara, pangan, sarana dan bangunan serta 
vektor dan binatang pembawa penyakit ${ }^{2}$.

Rumah sakit wajib memiliki prasarana yang salah satunya instalasi pengelolaan limbah. Pengelolaan limbah di rumah sakit dilaksanakan meliputi pengelolaan limbah padat, cair, bahan gas yang bersifat infeksius, bahan kimia beracun dan sebagian bersifat radioaktif, yang diolah secara terpisah $^{1}$.

Limbah merupakan sisa dari suatu usaha dan/atau kegiatan ${ }^{3}$. Barang atau bahan sisa hasil kegiatan yang tidak digunakan kembali yang berpotensi terkontaminasi oleh zat yang bersifat infeksius atau kontak dengan pasien dan/atau petugas di fasyankes (fasilitas pelayanan kesehatan) yang menangani pasien COVID-19, meliputi masker bekas, sarung tangan bekas, perban bekas, tisu bekas, plastik bekas minuman dan makanan, kertas bekas makanan dan minuman, alat suntik bekas, set infus bekas, Alat Pelindung Diri (APD) bekas, sisa makanan pasien dan lain-lain, berasal dari kegiatan pelayanan di UGD (Unit Gawat Darurat), ruang isolasi, ruang ICU (Intensive Care Unit), ruang perawatan, dan ruang pelayanan lainnya merupakan limbah B3 medis padat ${ }^{4}$.

Penelitian yang dilakukan Zuhriyani (2019) menyatakan bahwa ada perbedaan pelaksanaan sistem pengelolaan limbah medis padat di Rumah Sakit Raden Mattaher Jambi dengan Peraturan Menteri Lingkungan Hidup dan Kehutanan Nomor P.56/MenLHK-Setjen/2015 meliputi pemilahan, pengumpulan dan pengangkutan, sarana lokasi TPS, lama penyimpanan limbah hingga pemakaian APD petugas 5 .

Sedangkan penelitian yang dilakukan Asmarhany (2014) pada Rumah Sakit Umum Daerah Kelet Kabupaten Jember menyatakan daur ulang limbah medis padat berupa vial rumah sakit tersebut menggunakan autoclave termal kering. Namun masih terjadi kelalaian oleh petugas karena belum semuanya menggunakan APD pada saat pengangkutan limbah medis ${ }^{6}$.

Penanganan limbah B3 rumah sakit harus memperhatikan prinsip pengelolaan limbah B3 rumah sakit. Upaya-upaya yang wajib dilakukan adalah mengidentifikasi jenis limbah B3, memperhatikan tahapan penanganan pewadahan dan pengangkutan limbah B3 diruangan sumber, memperhatikan cara pengurangan dan pemilahan limbah B3, memperhatikan prasyarat bangunan TPS di rumah sakit, memperhatikan pemilahan limbah B3 di rumah sakit yang dilakukan di TPS limbah B3, memperhatikan cara penyimpanan sementara limbah B3, memperhatikan lamanya penyimpanan limbah B3 untuk jenis limbah karakteristik infeksius, benda tajam dan patologis di rumah sakit sebelum diangkut, memperhatikan cara pengangkutan limbah B3, hingga cara pengolahan limbah B $3^{2}$.

Limbah B3 (limbah infeksius) yang berasal dari fasyankes dalam penanganan COVID-19 dilakukan langkah-langkah penanganan berupa melakukan penyimpanan limbah infeksius dalam kemasan yang tertutup paling lama 2 (dua) hari sejak dihasilkan, mengangkut dan/atau memusnahkan pada pengolahan limbah B3 (fasilitas incenerator dengan suhu pembakaran minimal $800^{\circ} \mathrm{C}$ atau dengan autoclave yang dilengkapi dengan pencacah/shredder), residu hasil pembakaran atau cacahan hasil autoclave dikemas dan dilekati simbol "beracun" dan label limbah B3 yang selanjutnya disimpan di tempat penyimpanan sementara limbah B3 untuk selanjutnya diserahkan kepada pengelola limbah B3 ${ }^{7}$.

Provinsi Sulawesi Utara memiliki 49 RS dengan klasifikasi 43 RS merupakan Rumah Sakit Umum dan 6 RS Khusus (RSK/RSIA), sehingga melihat jumlah RS yang ada perlu diperhatikan pengelolaan limbah B3 yang meliputi pengurangan, penyimpanan, pengumpulan, pengangkutan, pemanfaatan, pengolahan dan/atau penimbunan sebagai limbah B3 medis padat sekaligus untuk mengendalikan, mencegah, dan memutuskan penularan COVID-19 serta menghindari penumpukan limbah yang ditimbulkan dari penanganan COVID-19.

Oleh sebab itu tujuan penelitian ini untuk mengetahui pengolahan limbah medis pada rumah sakit rujukan yang ada di Provinsi Sulawesi Utara yang ditimbulkan dari penanganan COVID-19.

\section{METODE}

Penelitian ini adalah penelitian kuantitatif bersifat observasional dengan desain penelitian cross sectional. Penelitian dilakukan pada 18 Rumah Sakit Rujukan COVID-19 yang berada di Provinsi Sulawesi Utara sebagai populasi penelitian. Sampel penelitian adalah semua anggota populasi.

Seluruh Rumah Sakit Rujukan COVID-19 ini adalah rumah sakit yang ditetapkan berdasarkan Surat Keputusan Menteri Kesehatan sebanyak 4 rumah sakit rujukan nasional dan 14 rumah sakit rujukan penunjang yang ditetapkan berdasarkan Surat Keputusan Gubernur Sulawesi Utara yang menjadikan rujukan sebagai komponen dalam sistem pelayanan kesehatan penanganan COVID-19. 
Jurnal Kesehatan Lingkungan

Vol.10, No.2, Oktober 2020, pp. 52 - 59

ISSN 2615-188X(Online), ISSN 2089 - 0451(Print)

DOI: $10.47718 / \mathrm{jkl} . v 10 \mathrm{i} 2.1162$

Journal homepage: https://ejurnal.poltekkes-manado.ac.id/index.php/jkl

Penelitian dilakukan pada bulan Mei - Juni 2020. Pengambilan sampel dilakukan secara primer dengan teknik sampling jenuh menggunakan instrument (kuesioner). Hasil penelitian disajikan dalam bentuk tabel dan dinarasikan.

\section{HASIL}

Penelitian pada Rumah Sakit ini berdasarkan Pedoman Pengelolaan Limbah Rumah
Sakit Rujukan, Rumah Sakit Darurat dan Puskesmas Yang Menangani Pasien COVID-19. Hasil yang dilaksanakan oleh peneliti dapat digambarkan sebagai berikut.

Penelitian dilaksanakan pada bulan Mei Juni 2020 oleh Petugas Kesehatan Lingkungan Dinas Kesehatan Daerah Povinsi Sulawesi Utara, dengan hasil sebagai berikut :

Tabel 1. Distribusi Status, Cara Pengolahan dan Status Insinerator Rumah Sakit Rujukan COVID-19 Tahun 2020

\begin{tabular}{ccc}
\hline Status Rumah Sakit & Frekuensi & Persentase \\
\hline RS Umum & 18 & 100,0 \\
RS Khusus & 0 & 0 \\
\hline Total & 18 & 100,0 \\
\hline Cara Pengolahan & Frekuensi & Persentase \\
\hline Insinerator & 11 & 61,1 \\
Pihak Ketiga & 7 & 38,9 \\
\hline Total & 18 & 100,0 \\
\hline Status Insinerator & Frekuensi & Persentase \\
\hline Berizin & 0 & 0 \\
Tidak Berizin & 11 & 100,0 \\
\hline Total & 11 & 100,0 \\
\hline
\end{tabular}

Tabel 1, menjelaskan bahwa seluruh rumah sakit rujukan COVID-19 yang ada di Sulawesi Utara merupakan rumah sakit umum sebanyak 18 rumah sakit (100\%). Dapat dilihat bahwa rumah sakit rujukan di Sulawesi Utara, cara pengolahan limbah medis COVID-19 paling banyak dilakukan dengan menggunakan insinerator yang dimiliki sendiri yaitu 11 rumah sakit $(61,1 \%)$ dan 7 rumah sakit $(38,9 \%)$ pengolahan limbah medis COVID-19 menggunakan jasa pihak ketiga. Dan seluruh rumah sakit yang mengolah limbah medis COVID-19 dengan menggunakan insinerator tidak memiliki izin operasional sebanyak 11 rumah sakit $(100 \%)$.

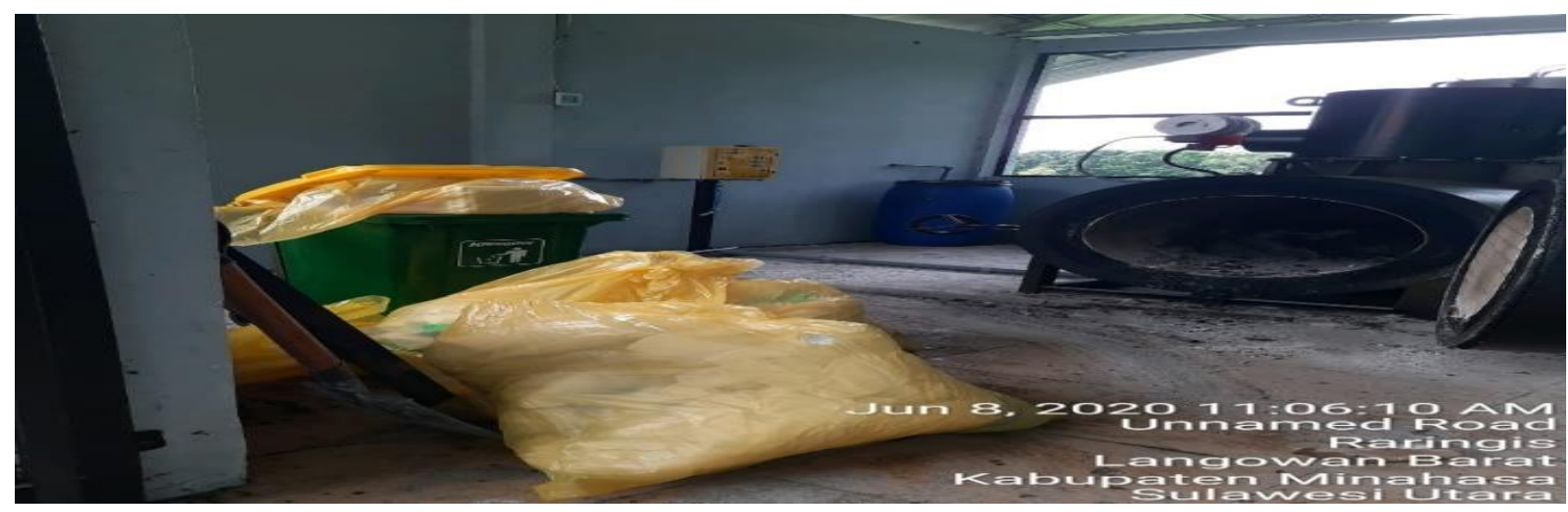

Gambar 1. Pembakaran Limbah Medis COVID-19 dengan Insinerator disalah satu Rumah Sakit Rujukan COVID-19 Provinsi Sulawesi Utara (Sumber : Dokumentasi Pribadi) 


\section{PEMBAHASAN}

Rumah Sakit Rujukan COVID-19 merupakan rumah sakit yang ditetapkan menjadikan rujukan sebagai komponen dalam sistem pelayanan kesehatan penanganan COVID-19. Rumah Sakit Umum merupakan Rumah Sakit yang memberikan pelayanan kesehatan pada semua bidang dan jenis penyakit dan Rumah Sakit Khusus merupakan Rumah Sakit yang memberikan pelayanan utama pada satu bidang atau satu jenis penyakit tertentu, berdasarkan disiplin ilmu, golongan umur, organ atau jenis penyakit.

Tahun 2020, Provinsi Sulawesi Utara memiliki 49 Rumah Sakit yang terbagi dari 43 Rumah Sakit Umum dan 6 Rumah Sakit Khusus. Provinsi Sulawesi Utara merupakan salah satu provinsi yang memiliki jumlah kasus COVID-19 yang banyak di Indonesia, sehingga memiliki rumah sakit rujukan COVID-19 dengan perincian : 4 rumah sakit rujukan dengan SK Menteri Kesehatan, 14 rumah sakit rujukan penunjang dengan SK Gubernur Sulawesi Utara, 27 rumah sakit rujukan pelengkap dengan SK Gubernur Sulawesi Utara, 1 rumah sakit rujukan dengan SK Bupati Sangihe ${ }^{8}$.

Pengelolaan limbah B3 merupakan suatu rangkaian kegiatan yang mencakup penyimpanan limbah B3, pengumpulan limbah B3, pemanfaatan, pengangkutan, dan pengolahan limbah B3 termasuk penimbunan limbah B3 hasil pengolahan tersebut. Rangkaian tersebut terkait beberapa pihak yang masing-masing merupakan mata rantai, yaitu: penghasil, pengumpul, pengangkut, pemanfaat, pengolah dan penimbun limbah $\mathrm{B} 3^{3}$.

Pengolahan limbah B3 adalah proses untuk mengurangi dan/atau menghilangkan sifat bahaya dan/atau sifat racun. Dalam pelaksanaannya, pengolahan limbah B3 dari fasilitas pelayanan kesehatan dapat dilakukan pengolahan secara termal atau nontermal. Pengolahan limbah B3 secara termal dapat dilakukan dengan menggunakan peralatan autoclave tipe alir gravitasi dan/atau tipe vakum, gelombang mikro, iradiasi frekwensi dan insinerator. Cara pengolahan secara non termal dapat dilakukan dengan enkapsulasi sebelum ditimbun, inertisasi sebelum ditimbun, dan desinfeksi kimiawi ${ }^{9}$.

Pengolahan limbah B3 yang menggunakan alat insinerator, perlu memperhatikan izin pengolahan limbah B3 dahulu terkait spesifikasi dan informasi insinerator, temperatur ruang bakar utama dan kedua serta ketinggian cerobong, kemudian melakukan uji coba pembakaran (trial burn test) sebelum insinerator dioperasikan secara terus menerus atau kontinue. Pada saat pengoperasian perlu juga memperhatikan pengoperasiannya, pemantauan, hingga pelaporan kepada Kementerian Lingkungan Hidup dan Kehutanan (KLHK) per semester ( 6 bulan sekali) ${ }^{9}$.

Rumah sakit rujukan pada penelitian ini yang mengolah limbah medis menggunakan insinerator milik sendiri tidak memiliki izin operasional, namun selain insinerator tersebut pada salah satu rumah sakit rujukan juga menggunakan alat autoclave yang telah berizin operasional dalam mengolah limbah medisnya.

Hal ini sejalan dengan KLHK yang menyatakan dari 132 rumah sakit rujukan COVID-19 yang ditunjuk pemerintah untuk merawat pasien COVID-19, baru 20 rumah sakit yang memiliki insinerator berizin. Di sisi lain, dari total 2.889 rumah sakit yang beroperasi, baru 110 rumah sakit saja yang memiliki fasilitas insinerator berizin dengan 14 jasa pengelola limbah medis B3 dan 140 jasa pengangkut limbah $\mathrm{B} 3^{10}$.

Sebagaimana penelitian yang dilakukan Ma, Yufeng dkk (2020), penerapan penanganan limbah medis yang disebabkan oleh COVID-19 di beberapa Kota di China menggunakan insinerator dalam pengolahannya. Diantaranya Kota Shanghai dalam 6 tahun terakhir pengolahan limbah medis menggunakan sistem insinerasi menjadi metode pembuangan yang dinormalisasi setelah transformasi teknis dari fasilitas insenerasi limbah padat perkotaan dan manajemen kesehatan dalam pencegahan epidemi ${ }^{11}$.

Proses insinerasi memiliki keuntungan dalam mengurangi volume limbah, namun kerugiannya dalam pembiayaan yang tinggi, timbulnya asap serta risiko polusi ${ }^{12}$. Dalam proses insenerasi, volume sampah yang tersisa untuk dibuang akan berkurang 50 - 400 kali lipat ${ }^{13}$.

Penelitian yang dilakukan Peng Jie dkk (2020) menyatakan limbah medis terkait COVID-19 diutamakan diolah dengan insinerasi suhu tinggi. Meskipun gas yang dibuang selama proses insinerasi akan menyebabkan pencemaran udara. Studi sebelumnya menunjukkan bahwa insinerasi adalah cara yang paling umum dan efektif untuk membunuh patogen infeksius, dan dapat diterapkan pada berbagai limbah medis yang menular ${ }^{14}$.

Bagi fasyankes yang tidak melakukan pengolahan limbah medis dengan insinerator, limbah medis dapat juga diproses dengan sanitary 
landfill setelah dikukus dan direbus pada suhu tinggi ${ }^{14}$. Adapula fasyankes menggunakan penyedia pengelolaan limbah layanan kesehatan swasta (jasa pihak ketiga) dan 92\% diantaranya berlokasi di Pulau Jawa. Jarak yang jauh dari rumah sakit ke tempat pembuangan akhir limbah medis dapat meningkatkan risiko pembuangan ilegal, kontaminasi silang dan penularan penyakit karena meningkatnya kemungkinan kecelakaan atau kesalahan manusia selama waktu pengangkutan yang diperpanjang ${ }^{15}$.

Pihak ketiga dalam pengelolaan limbah ini berasal dari 2 (dua) perusahaan, yaitu PT. Tenang Jaya Sejahtera (TJS) dan PT. Mitra Hijau Asia (MHA). PT. Tenang Jaya Sejahtera (TJS) merupakan perusahaan jasa yang didirikan pada tahun 2008 bergerak dalam bidang industri jasa pengangkutan dan pengumpulan serta pengelolaan (pengolahan dan pemanfaatan) yang telah mempunyai izin dari Kementerian Lingkungan Hidup (KLH) maupun izin dari Instansi lainnya. Perusahaan ini berlokasi di Kabupaten Karawang, Jawa Barat dan dalam melakukan kegiatan usahanya perusahaan ini mengikuti kaidah EHSC (Environmental, Health, Safety and Compliance), dimulai dari pembersihan, pengangkutan, pengumpulan serta pengelolaan. Adapun proses pengolahan limbah B3 yang dimiliki oleh PT. Tenang Jaya Sejahtera antara lain WWTP dengan sistem Elektrocoogulation, Distilasi pada pengolahan solvent bekas, incenerator B3 untuk limbah infeksius (medis) dan tungku pembakaran untuk pemusnahan produk expired/kadaluarsa maupun gagal produk (offspec) ${ }^{16}$.

PT. Mitra Hijau Asia atau MHA merupakan perusahaan pengumpul dan pengangkutan limbah berbahaya dan beracun (limbah B3) yang menerapkan konsep EHSC (environment, health, safety, compliance) sebagai kaidah pelaksanaan seluruh kegiatan mulai dari pembersihan, pengangkutan dan pengumpulan limbah B3, berlokasi di Makassar, Sulawesi Selatan dan telah memiliki izin dari Kementerian Lingkungan Hidup dan Kehutanan serta Kementerian Perhubungan ${ }^{17}$.

Limbah infeksius yang dihasilkan pada masa pandemi COVID-19 ini mengalami peningkatan. Tercatat bulan Maret 2020 total limbah baik APD dan limbah medis yang diolah di insinerator berjumlah $4500 \mathrm{~kg}$. Kementerian Kesehatan memprediksi limbah medis yang dihasilkan Indonesia per hari sebanyak 294,66 ton dengan selisih 70,432 ton per hari, padahal kapasitas pengolahan limbah medis fasyankes baru mencapai 53,12 ton per hari ditambah kapasitas pengolahan oleh pihak ketiga sebesar 187,90 ton per hari ${ }^{18}$.

Penelitian yang dilakukan Prasetiawan (2020) terkait permasalahan limbah medis COVID19 menyatakan bahwa Indonesia masih bergantung pada insinerator sebagai teknologi pengolahan limbah, sehingga pemerintah perlu menciptakan iklim investasi yang sehat bagi jasa pengolah dan pengangkutan limbah medis, serta pemerintah perlu mengembangkan skema pembiayaan dalam mendukung pengelolaan limbah medis saat ini ${ }^{19}$.

Penanganan limbah B3 medis padat perlu memperhatikan langkah-langkahnya. Limbah B3 medis dimasukkan ke dalam wadah/bin yang dilapisi kantong plastik warna kuning yang bersimbol "biohazard". Hanya limbah B3 medis berbentuk padat yang dapat dimasukkan ke dalam kantong plastik limbah B3 medis. Bila di dalamnya terdapat cairan, maka cairan harus dibuang ke tempat penampungan air limbah yang disediakan atau lubang di wastafel atau WC yang mengalirkan ke dalam IPAL (Instalasi Pengolahan Air Limbah). Setelah $3 / 4$ penuh atau paling lama 12 jam, sampah/limbah B3 dikemas dan diikat rapat. Limbah Padat B3 Medis yang telah diikat setiap 24 jam harus diangkut, dicatat dan disimpan pada TPS (Tempat Penampungan Sementara) Limbah B3 atau tempat yang khusus. Petugas wajib menggunakan APD lengkap ${ }^{4}$.

Pengumpulan limbah B3 medis padat ke TPS Limbah B3 dilakukan dengan menggunakan alat transportasi khusus limbah infeksius dan petugas menggunakan APD. Berikan simbol Infeksius dan label, serta keterangan "Limbah Sangat Infeksius, Infeksius Khusus". Limbah B3 Medis yang telah diikat setiap 12 jam di dalam wadah/bin harus diangkut dan disimpan pada TPS Limbah B3 atau tempat yang khusus. Pada TPS Limbah B3 kemasan sampah/limbah B3 COVID-19 dilakukan disinfeksi dengan menyemprotkan disinfektan (sesuai dengan dosis yang telah ditetapkan) pada plastik sampah yang telah terikat. Setelah selesai digunakan, wadah/bin didisinfeksi dengan disinfektan seperti klorin 0,5\%, lysol, karbol, dan lain-lain. Limbah B3 Medis padat yang telah diikat, dilakukan disinfeksi menggunakan disinfektan berbasis klorin konsentrasi $0,5 \%$ bila akan diangkut ke pengolah ${ }^{4}$.

Pengangkutan dilakukan dengan menggunakan alat transportasi khusus limbah dan petugas menggunakan APD. Petugas pengangkut yang telah selesai bekerja melepas APD dan segera 
mandi dengan menggunakan sabun antiseptik dan air mengalir ${ }^{4}$.

Dalam hal tidak dapat langsung dilakukan pengolahan, maka limbah dapat disimpan dengan menggunakan freezer/cold-storage yang dapat diatur suhunya di bawah $0^{\circ} \mathrm{C}$ di dalam TPS. Melakukan disinfeksi dengan disinfektan klorin 0,5\% pada TPS Limbah B3 secara menyeluruh, sekurang-kurangnya sekali dalam sehari ${ }^{4}$.

Pengolahan limbah B3 medis dapat menggunakan insinerator/autoclave/gelombang mikro. Dalam kondisi darurat COVID-19, penggunaan peralatan tersebut memungkinkan fasyankes mengoperasikan insinerator tanpa izin selama tahap finalisasi proses perolehan $\operatorname{izin}^{15}$. Pengolahan limbah medis B3 COVID-19 harus dilakukan sesuai dengan Surat Edaran Menteri LHK Nomor SE.02/ PSLB3/ PLB.3/3/ 2020 dimana digunakan insinerator limbah B3 dengan temperatur pembakaran minimal $800^{\circ} \mathrm{C}$ dengan prosedur pengelolaan, pengoperasian dan pemantauan yang ketat $^{7}$.

Untuk fasyankes yang menggunakan insinerator, abu/residu insinerator agar dikemas dalam wadah yang kuat untuk dikirim ke penimbun berizin. Bila tidak memungkinkan untuk dikirim ke penimbun berizin, abu/residu insinerator dapat dikubur sesuai konstruksi yang ditetapkan ${ }^{9}$.
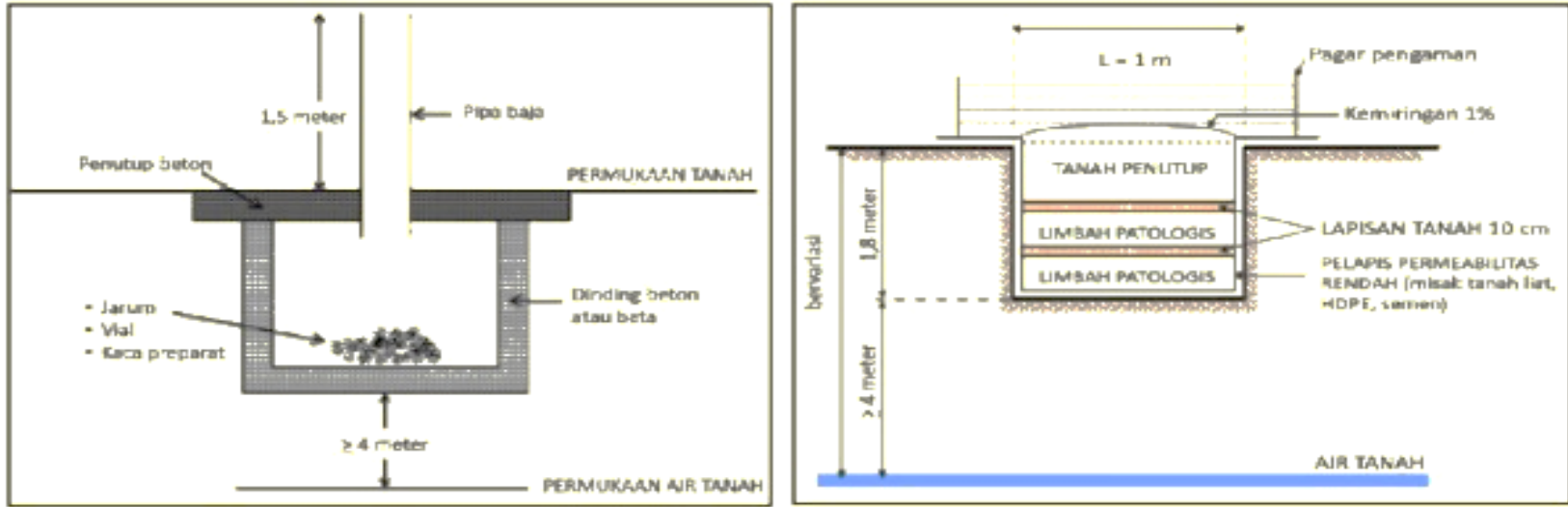

Gambar 2. Konstruksi Penguburan Limbah B3 COVID-19

Pengolahan juga dapat menggunakan jasa perusahaan pengolahan yang berizin, dengan melakukan perjanjian kerjasama pengolahan. Pengolahan harus dilakukan sekurang-kurangnya 2 x 24 jam. Timbulan/volume limbah B3 harus tercatat dalam logbook setiap hari dan memilki manifest limbah B3 yang telah diolah. Melaporkan pada Kementerian Lingkungan Hidup dan Kehutanan terkait jumlah limbah B3 medis yang dikelola melalui Dinas Lingkungan Hidup Provinsi/ Kabupaten/Kota.
KLHK berencana membangun fasilitas pengelolaan limbah kesehatan (insinerator) pada 5 Provinsi. KLHK juga merekomendasikan agar fasilitas kesehatan di bawah pengawasan Dinas Kesehatan Provinsi dan Kabupaten berkoordinasi dengan industri seperti industri semen untuk mengelola pembuangan limbah kesehatan mereka ${ }^{15}$.

Untuk fasyankes yang menggunakan autoclave/gelombang mikro, residu agar dikemas dalam wadah yang kuat. Residu dapat dikubur dengan konstruksi yang ditetapkan pada Peraturan Menteri Lingkungan Hidup dan Kehutanan Nomor 56 Tahun 2015. Untuk fasyankes yang tidak memiliki peralatan tersebut dapat langsung melakukan penguburan dengan langkah-langkah sebagai berikut:

a. Limbah didisinfeksi terlebih dahulu dengan disinfektan berbasis klor $0,5 \%$

b. Limbah dirusak supaya tidak berbentuk asli agar tidak dapat digunakan kembali

c. Dikubur dengan konstruksi yang ditetapkan pada Peraturan Menteri Lingkungan Hidup dan Kehutanan Nomor 56 Tahun 2015.

Konstruksi penguburan limbah B3 COVID19 sesuai Peraturan Menteri Lingkungan Hidup dan Kehutanan nomor 56 Tahun 2015 adalah sebagaimana gambar berikut ini:

\section{KESIMPULAN}

Kesimpulan dalam penelitian ini adalah dari 18 rumah sakit rujukan COVID-19 di Provinsi Sulawesi Utara, ada 11 rumah sakit rujukan mengelola limbah medis COVID-19 dengan menggunakan alat insinerator yang dimiliki rumah sakit sendiri dan semuanya tidak memiliki izin operasional dari Kementerian Lingkungan Hidup dan Kehutanan (KLHK). Namun dalam kondisi 
darurat (pandemi COVID-19), pengolahan limbah B3 medis dapat menggunakan alat insinerator dikecualikan untuk memiliki izin.

\section{SARAN}

Diharapkan semua fasyankes yang memiliki alat pengolahan limbah medis baik insinerator maupun autoclave yang belum berizin operasional sekalipun dalam masa darurat pandemi COVID-19, untuk tetap mengawal progres pengurusan dokumen izin operasional alat pengolahan limbah medis ini, sehingga ketikapun pandemi ini berakhir semua alat pengolahan limbah medis sudah memenuhi standar yang dipersyaratkan sesuai aturan yang berlaku.

Dinas Kesehatan Provinsi/Kabupaten/Kota dan Dinas Lingkungan Hidup Provinsi/Kabupaten/Kota harus tetap terus memantau pengelolaan limbah medis fasyankes terlebih pada masa pandemi COVID-19.

\section{UCAPAN TERIMA KASIH}

Terimakasih kepada Pemerintah Provinsi Sulawesi Utara terlebih pada Dinas Kesehatan Daerah Provinsi Sulawesi Utara yang telah membantu dalam kegiatan penelitian atau tulisan ini.

\section{DAFTAR PUSTAKA}

1. Pemerintah Indonesia. Undang-Undang RI Nomor 44 Tahun 2009 tentang Rumah Sakit. 2009.

2. Kementerian Kesehatan RI. Peraturan Menteri Kesehatan RI Nomor 7 Tahun 2019 tentang Kesehatan Lingkungan Rumah Sakit. Jakarta; 2019.

3. Pemerintah Indonesia. Peraturan Pemerintah Nomor 101 Tahun 2014 tentang Pengelolaan Limbah Berbahaya dan Beracun. 2014.

4. Kementerian Kesehatan RI. Pedoman Pengelolaan Limbah Rumah Sakit Rujukan, Rumah Sakit Darurat Dan Puskesmas Yang Menangani Pasien Covid-19. Jakarta; 2020.

5. Zuhriyani. Analisis Sistem Pengelolaan Limbah Medis Padat Berkelanjutan di Rumah Sakit Umum Raden Mattaher Jambi. J Pembang Berkelanjutan [Internet]. 2019;1.(1). Available from: https://onlinejournal.unja.ac.id/JPB/article/view/6436

6. Asmarhany CD. Pengelolaan Limbah Medis Padat Di Rumah Sakit Umum Daerah Kelet Kabupaten Jepara. 2014.
7. Kementerian Lingkungan Hidup dan Kehutanan. Surat Edaran Menteri Lingkungan Hidup dan Kehutanan (LHK) Nomor SE.02/PSLB3/PLB.3/3/2020 tentang Pengelolaan Limbah Infeksius (Limbah B3) dan Sampah Rumah Tangga dari Penanganan Corona Virus Disease (COVID-19). 2020.

8. Pemerintah Provinsi Sulawesi Utara. Data Existing Ketersediaan Tempat Tidur dan Jumlah Pasien Covid-19 di Rumah Sakit Rujukan Utama dan Rujukan Penunjang Covid-19 Provinsi Sulawesi Utara. Manado; 2020.

9. Kementerian Lingkungan Hidup dan Kehutanan. Peraturan Menteri Lingkungan Hidup dan Kehutanan RI Nomor 56 Tahun 2015 tentang Tata Cara dan Persyaratan Teknis Pengelolaan Limbah Bahan Berbahaya dan Beracun dari Fasilitas Pelayanan Kesehatan. 2015.

10. Soemiarno SS. Penanganan Limbah B3 Infeksius COVID-19: Analisa Gap Kapasitas dan Alternaif Solusi. Disampaikan pada Webinar Pengelolaan Limbah B3 Medis dan Sampah Rumah Tangga COVID19 di Indonesia, 28 April 2020. Jakarta; 2020

11. Ma Y, Lin X, Wu A, Huang Q, Li X, Yan J. Suggested Guidelines For Emergency Treatment of Medical Waste During COVID-19: Chinese Experience. Waste Dispos Sustain Energy [Internet]. 2020;2(2):81-4. Available from: https://doi.org/10.1007/s42768-020-00039-8

12. Shareefdeen ZM. Medical Waste Management and Control. J Environ Prot (Irvine, Calif). 2012;3.

13. Rutberg P, Bratsev AN, Safronov AA, Surov A, Schegolev V V. The Technology And Execution of Plasmachemical Disinfection of Hazardous Medical Waste. Plasma Sci IEEE Trans. 2002 Sep 1;30:1445-8.

14. Peng J, Wu X, Wang R, Li C, Zhang Q, Wei D. Medical Waste Management Practice During The 2019-2020 Novel Coronavirus Pandemic: Experience In a General Hospital. Am J Infect Control. 2020;8:91821.

15. WHO. Safe Waste Management During COVID-19 Response. 2020; Available from: https://www.who.int/indonesia/news/detail/2 1-07-2020-safe-waste-management-duringcovid-19-response 
Jurnal Kesehatan Lingkungan

Vol.10, No.2, Oktober 2020, pp. 52 - 59

ISSN 2615-188X(Online), ISSN 2089 - 0451(Print)

DOI: $10.47718 / \mathrm{jkl} . v 10 \mathrm{i} 2.1162$

Journal homepage: https://ejurnal.poltekkes-manado.ac.id/index.php/jkl

16. PT. Tenang Jaya Sejahtera. PT. Tenang Jaya Sejahtera [Internet]. 2020 [cited 2020 Jun 30]. Available from: www.tenangjaya.co.id

17. PT. Mitra Hijau Asia. PT. Mitra Hijau Asia Protect The Environment [Internet]. 2016 [cited 2020 Jun 30]. Available from: www.mitrahijau.com

18. Nurali IA. Pengelolaan Limbah B3 Medis dan Sampah Terkontaminasi COVID-19. Disampaikan pada Webinar Pengelolaan Limbah B3 Medis dan Sampah Rumah Tangga COVID-19 di Indonesia, 28 April 2020. Jakarta; 2020.

19. Prasetiawan T. Permasalahan Limbah Medis Covid-19 Di Indonesia. Info Singk Bid Kesejaht Sos. 2020;XII No.9 P:13. 